\title{
FACTORS ASSOCIATED WITH YEARS OF LIFE WITH DISABILITY IN PATIENTS WITH LEPROSY: A PATH ANALYSIS EVIDENCE FROM KELET HOSPITAL, CENTRAL JAVA
}

\author{
Umi Nadhiroh'), Ruben Dharmawan²), Bhisma Murti') \\ ${ }^{1)}$ Masters Program in Public Health, Universitas Sebelas Maret \\ 2)Faculty of Medicine, Universitas Sebelas Maret
}

\begin{abstract}
Background: Leprosy, also known as Hansen's disease (HD), is a long-term infection by the bacterium Mycobacterium leprae or Mycobacterium lepromatosis. World Health Organization (WHO) reported that the number of leprosy casesin 2015 was 211,973 in 108 countries in the world. The number of leprosy cases in Indonesia ranks third after India and Brazil. There are 14,000 (8\%) leprosy cases with disability. This study aimed to determine factors affecting disability and Years of Life with Disability (YLD) attributable to leprosy in patients with leprosy at Kelet Hospital, Central Java.

Subjects and Method: This was a case control study conducted at Kelet Hospital, Central Java, from December 2017 to January 2018. A total sample of 140 leprosy patients was selected for this study using fixed disease sampling, consisting of 70 patients with disability and 70 patients without disability. The dependent variables were disability and YLD. The independent variables were age, education level, and self care. The data were collected by questionnaire and analyzed by path analysis.

Results: Disability increases YLD ( $b=0.37 ; 95 \% \mathrm{CI}=0.31$ to $0.43 ; \mathrm{p}<0.001$ ). Disability increased with older age $(\mathrm{b}=1.41 ; 95 \% \mathrm{CI}=0.38$ to $2.43 ; \mathrm{p}=0.007)$ and decreased with better self care $(b=-3.80 ; 95 \% C I=-4.90$ to $-2.71 ; p<0.001)$. Better self care increased with high education level $(b=1.96 ; 95 \% \mathrm{CI}=1.03$ to 2.89; $\mathrm{p}<0.001$ ).

Conclusion: Older age increases the risk of disability, whereas self care decreases the risk of disability. Disability itself increases YLD. Higher education improves self care.
\end{abstract}

Keywords: leprosy, disability, years of life with disability, determinant

Correspondence:

Umi Nadhiroh. Masters Program in Public Health, Universitas Sebelas Maret, Jl. Ir. Sutami 36 A, Surakarta, 57126, Central Java.

Email: umi.nadhiroh2@gmail.com. Mobile: 085727056553. 